\title{
Determination of the Growth Rates of Spirolina and Cheatoceros Algae in Urban Waste Sewage and their Capability to Deplete Nitrate and Phosphate Content in the Sewage
}

\author{
${ }^{* 1}$ LAVAJOO F; ${ }^{1}$ TAHERIZADEH M

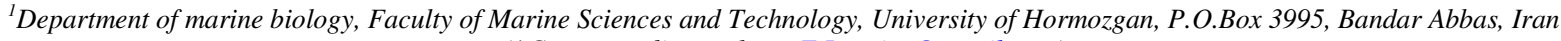 \\ (*Corresponding author: F.Lavajoo@gmail.com)
}

\begin{abstract}
The application of cyanobacterial and diatom cultures for the treatment of industrial effluents has been well recognized.In this study aimed to evaluate the effect of urban sewage on growth of Spirolina plantensis and Chaetoceros muelleri. The experiment was conducted in 6 treatments as a growth medium. Result showed that in treatment 5 maximum cell densities was $\left(565 \times 10^{2} \pm 237.7\right)$ at day7 thus treatment 5 has best condition for growth $S$. plantensis and in treatment 3 maximum cell density was $\left(825 \times 10^{4} \pm 92\right)$ at day13.Treatment 5 has best condition for growth $C$. muelleri. Total chlorophyll a, contents $(\mu \mathrm{g} / 1)$ recorded in $S$. Plantensi sand C. muelleri was highest at treatment $3(0.21 \pm 0.07)$ and treatment $4(0.23 \pm 0.10)$ respectively. In present investigation, both the algal species can be good potential to growth in urban sewage. The urban sewage removal efficiency of $C$. muelleri was higher as compare to S.plantensis which can be recommended for phytoremediation purpose. ( JASEM

http://dx.doi.org/10.4314/jasem.v20i3.24
\end{abstract}

Keywords: Spirolina; Chaetoceros;Nitrate and phosphate; Chlorophyll a;Urban sewage; Depletion.

The pollution increase, industrialization and rapid economic development, are cause of decrease the availability and quality of water resources, in many areas worldwide.Nowadays, uncontrolled discharge from industrial sectors or agriculture discharged to aquatic ecosystems and contaminated total aquatic environment which, not only cause toxic effect on human, via accumulation in aquatic animals, through food chain but also affect biodiversity (Lavajoo et al. 2015). Wastewater generated from urban or industry sewage sources contain high concentrations of organic matter, nitrogen and phosphorus, and causes eutrophication in receiving water. Urban sewages contain nutrients (which have been identified as the main causes leading to eutrophication in natural waters) must be treated before being discharged into water bodies (Mallick, 2002). Instances of the effect of sewages on microalgae growth are arrested cell division, inhibited growth rate, restrained enzyme activity and reduced photosynthesis (Chen et al., 2009; Baumann and Morrison, 2009). Compared to other aquatic organisms in marine environment, unicellular microalgae exhibit highest resistant to sewages and highly recommended as bio-indicator for the assessment of marine pollution (Rijstenbeil et al., 1994; Kapkov and Belenikina, 2003; Kapkov and Belenikina, 2007). The use of several microalgae cultures in wastewater treatment has a major advantage that allows effective utilizing of nutrients (De la Noue et al.,1992). Microalgae culture systems can be employed in different processes, such as wastewater treatment and production of animal food
(De la Noue and Proulx, 1988). The wastewater treatment by microalgae and cyanobacteria is known (De la Noue et al., 1993; De la Noue and Proulx, 1988; Oswald, 1988).In fact, traditional wastewater treatment process required high operation cost to provide suitable condition for aerobic bacteria to effectively consume organic components in polluted water. However, microalgae provide an efficient lowcost approach to treat wastewater (Lananan et al., 2014; Nasir et al., 2015).Recent studies showed that many algal species, especially Chlamydomonas, Scenedesmus and Chlorella decreased nutrients under light condition (mixotrophy) and they are also capable of heterotrophic growth on simple molecules, such as acetate, glucose and organic acids in the dark (Laliberte andDe la Noue, 1993).It has been suggested that a Microalgae have been offered as bioremediation treatment to decrease $\left(\mathrm{NH}_{4}{ }^{+}, \mathrm{NO}_{3}{ }^{-}\right.$and $\left.\mathrm{PO}_{4}{ }^{3-}\right)$ nutrients (Mallick, 2002).The presence of high concentrations of ammonia and urea in urban sewages inhibit algal growth and physiological activity (Przytocka-Jusiak, 1976).Therefore, in the present study the growth rates and amount of nitrate and phosphate absorptionof Spirolina plantensis and Chaetoceros muelleri on urban wastewater were determined.

\section{MATERIALS AND METHODS}

Test Species: In this study the microalgae cultures of marine blue green algae (Spirolina plantensis) and Diatom (Chaetoceros muelleri) were obtained from the phytoplankton culture laboratory, of institution Persian Gulf and Omani Sea Hormozgan in Iran. The

*Corresponding author: F.Lavajoo@gmail.com) 
urban sewage was collected from discharged refinery site of Bandar Abbas.

Experimental Design: In the laboratory, the samples of sewage were filtered through a $25 \mathrm{~mm}, 3 \mu \mathrm{m}$ glass microfiber filters (GF/C) mounted on a Millipore filtration unit and sterilized by autoclavingat $121^{\circ} \mathrm{C}$ for 15 minutes. The culture growth medium prepared with three replicates for conducting the experiments and the duration was 15 days under similar laboratory conditions at temperature $\left(30^{\circ} \mathrm{C} \pm 2^{\circ} \mathrm{C}\right)$ for Spirolina plantensisand Temperature $\left(25^{\circ} \mathrm{C} \pm 2^{\circ} \mathrm{C}\right)$ for Chaetoceros muelleri; Light (2500 \pm 500) lux forSpirolinaplantensisand Light $(4500 \pm 500)$ lux for Chaetoceros, optimum $\mathrm{pH}$ was between 8.0 and 11 for Spirolina plantensis and for Chaetoceros muelleri was between 9.0 and 11, that adjusted by electronic pH meter (ELICO, Model LI 120) and with constant aeration.

Treatments A:(1) Spirolina plantensis was cultivated in f/2 Medium based on (Guillard, 1975). (2) Spirolinaplantensis was cultivated in $80 \%$ of filtered seawater and $20 \%$ urban waste (3)Spirolina plantensis was cultivated in $60 \%$ of filtered seawater and $40 \%$ urban waste (4) Spirolina plantensis was cultivated in $40 \%$ of filtered seawater and $60 \%$ urban waste (5)Spirolina plantensis was cultivated in $20 \%$ of filtered seawater and $80 \%$ urban waste (6) Spirolina plantensis was cultivated in $100 \%$ urban waste. Total volume of culture and media was $200 \mathrm{ml}$.

Treatments B:(1) Chaetoceros muelleri was cultivated in f/2 Medium based on (Guillard, 1975) (2) Chaetoceros muelleri was cultivated in $80 \%$ of filtered seawater and $20 \%$ urban waste (3)Chaetoceros muelleri was cultivated in $60 \%$ of filtered seawater and $40 \%$ urban waste (4) Chaetoceros muelleri was cultivated in $40 \%$ of filtered seawater and $60 \%$ urban waste (5)Chaetoceros muelleri was cultivated in $20 \%$ of filtered seawater and $80 \%$ urban waste(6) Chaetoceros muelleri was cultivated in $100 \%$ urban waste. Total volume of culture and media was $200 \mathrm{ml}$.

Cell density and Growth Rate: The cell growth was monitored by measuring cell numbers by manual counting under the binocular light microscope. Growth rates were calculated as $\mu$. day ${ }^{-1}$ according to the following Formula $\mu=\left(\mathrm{N} 1 / \mathrm{N}_{0}\right) / \mathrm{t}$; Where, N0 and N1 represent cell density at the start and the end of the growth period, and tare the time between measurements (in days).

Physicochemical analysis: Water quality analysis of ammonia and phosphorus (orthophosphate) determination were based on Phenate Method and Vanadomolybdo phosphoric Acid Method adapted from the Standard Method for the Examination of Water and Wastewater (APHA, 2005) . Sampled water was clarified from the MA and EM biomass by centrifugation at $5000 \mathrm{rpm}, 15 \mathrm{~min}$ to obtain clear supernatant which was subjected immediately to water quality analysis for the determination of ammonia and phosphorus. Nitrate and chlorophylla, were also measured by spectrophotometer UV/visible (Variancarry 100) according to Manual of Oceanographic Observations and Pollutant Analysis Methods procedures (Marine environment assessment marine meteorology, 1999).

Statistical analysis: To test whether there was statistical difference among the cell density between Chaetoceros muelleri and Spirolina plantensis in different days, we performed a Student's t-test. The mean and standard deviation values of the triplicates for each treatment were calculated. The results were analyzed statistically by using Spss 17 software and graphical analyses were performed using Microsoft Office Excel.

\section{RESULTS AND DISCUSSION}

Growth of Spirolina plantensis at different treatments: In the present study, the number of Spirolina cells at different treatments was shown. In treatment $1(100 \%$ f/2 Medium) cells appeared to reach their stationary phase after 11 days of cultivation and started to decline thereafter. In treatment 1 maximum and minimum cell density were $\left(588 \times 10^{2} \pm 121\right)$ and $\left(48 \times 10^{2} \pm 8\right)$ for day11 and day 3 respectively. One- way analysis of variance (ANOVA), showed significant difference between days and cell density $(\mathrm{P}<0.05)$. All analyses were performed at $5 \%$ statistical significance level. In treatment $2(80 \%$ f/2 Medium+ $20 \%$ urban waste) cells appeared to reach their stationary phase after 9days of cultivation and started to decline thereafter. In treatment 2 maximum and minimum cell density were $\left(116 \times 10^{2} \pm 16\right)$ and $\left(52 \times 10^{2} \pm 8\right)$ for day 9 and day 15 respectively. In one- way analysis of variance (ANOVA), between days and cell density did not observed significant difference $(\mathrm{P}>0.05)$. All analyses were performed at 5\% statistical significance level. In treatment 3 (60\% f/2 Medium+ $40 \%$ urban waste) cells appeared to reach their stationary phase after 11days of cultivation and started to decline thereafter. In treatment 3 maximum and minimum cell density were $\left(357 \times 10^{2} \pm 92\right)$ and $\left(54 \times 10^{2} \pm 18.5\right)$ for day 11 and day 3 respectively. One- way analysis of variance (ANOVA), showed significant difference between days and cell density $(\mathrm{P}<0.05)$. All analyses were performed at 5\% statistical significance level. In treatment $4(40 \%$ f/2 Medium+ $60 \%$ urban waste) cells appeared to reach their stationary phase after 
11days of cultivation and started to decline thereafter. In treatment 4 maximum and minimum cell density were $\left(424.7 \times 10^{2} \pm 62.1\right)$ and $\left(60 \times 10^{2} \pm 6.1\right)$ for day 11 and day 3 respectively. One- way analysis of variance (ANOVA), showed significant difference between days and cell density $(\mathrm{P}<0.05)$. All analyses were performed at $5 \%$ statistical significance level. In treatment $5(20 \%$ f/2 Medium+ $60 \%$ urban waste) cells appeared to reach their stationary phase after 11days of cultivation and started to decline thereafter. In treatment 5 maximum and minimum cell density were $\left(565 \times 10^{2} \pm 237.7\right)$ and $\left(80 \times 10^{2} \pm 7.1\right)$ for day 7 and day 3 respectively. One- way analysis of variance
(ANOVA), showed significant difference between days and cell density $(\mathrm{P}<0.05)$. All analyses were performed at $5 \%$ statistical significance level. In treatment $6(100 \%$ urban waste) cells appeared to reach their stationary phase after 11days of cultivation and started to decline thereafter. In treatment 5 maximum and minimum cell density were $\left(417 \times 10^{2} \pm 190.7\right)$ and $\left(56.4 \times 10^{2} \pm 15.9\right)$ for day11 and day 3 respectively. One- way analysis of variance (ANOVA), showed significant difference between days and cell density $(\mathrm{P}<0.05)$. All analyses were performed at $5 \%$ statistical significance level (Fig.1) (Table.1).

Table.1. Cell density of Spirolina plantensis and Chaetoceros muelleri at the end of test period (day 15)

\begin{tabular}{ccccc}
\hline Treatments & Spirolina $\left(\times 10^{2}\right.$ cell $\left./ \mathrm{ml}\right)$ & \multicolumn{3}{c}{ Chaetoceros $\left(\times 10^{4}\right.$ cell $\left./ \mathrm{ml}\right)$} \\
& Mean & Std. & 324.02 & Std. \\
\hline Treatment1 & 275.90 & 181.46 & 539.66 & 250.97 \\
Treatment2 & 83.07 & 27.78 & 664.95 & 234.47 \\
Treatment3 & 180.71 & 100.76 & 424.16 & 236.74 \\
Treatment & 264.71 & 161.86 & 475.88 & 205.67 \\
Treatment5 & 333.0 & 222.51 & 328.17 \\
Treatment6 & 320.61 & 202.18 & 305.80 & 252.74 \\
\hline
\end{tabular}

Impact of different treatments and days on the growth of Spirolina plantensis: To determination of best treatment condition and lowest time for highest Spirolina plantensis growth we used of two- way analysis of variance (ANOVA). We observed a strong positive correlation $\left(\mathrm{R}^{2}=0.82\right)$ between treatment conditions and times for Spirolina plantensis growth (Fig.2).
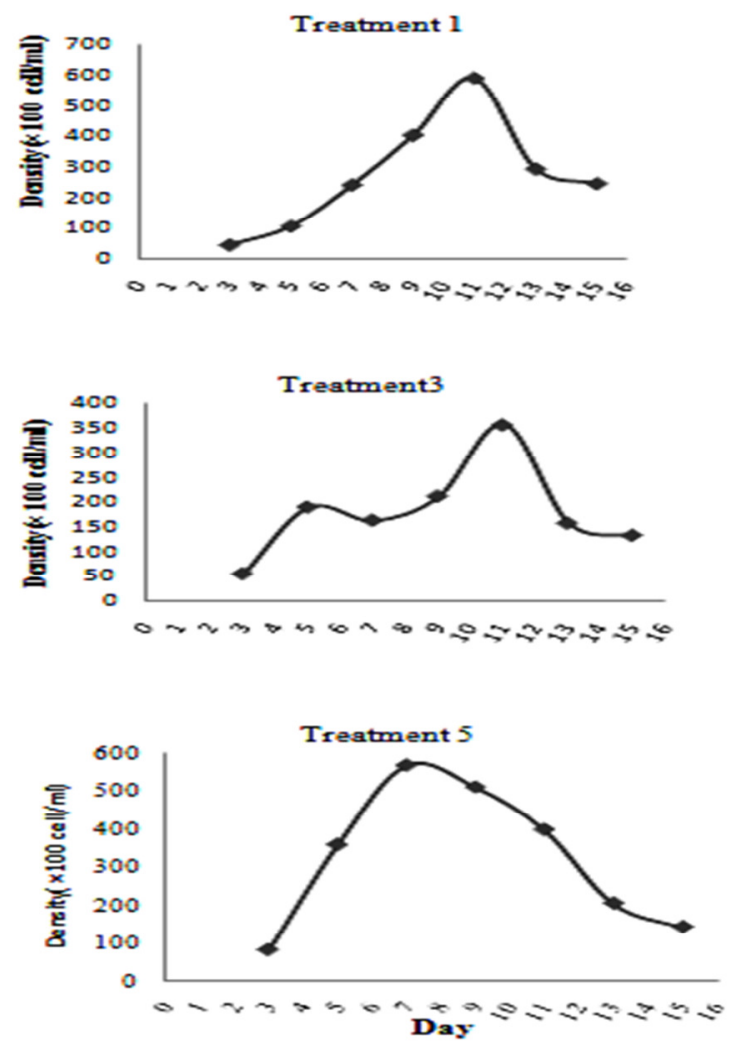
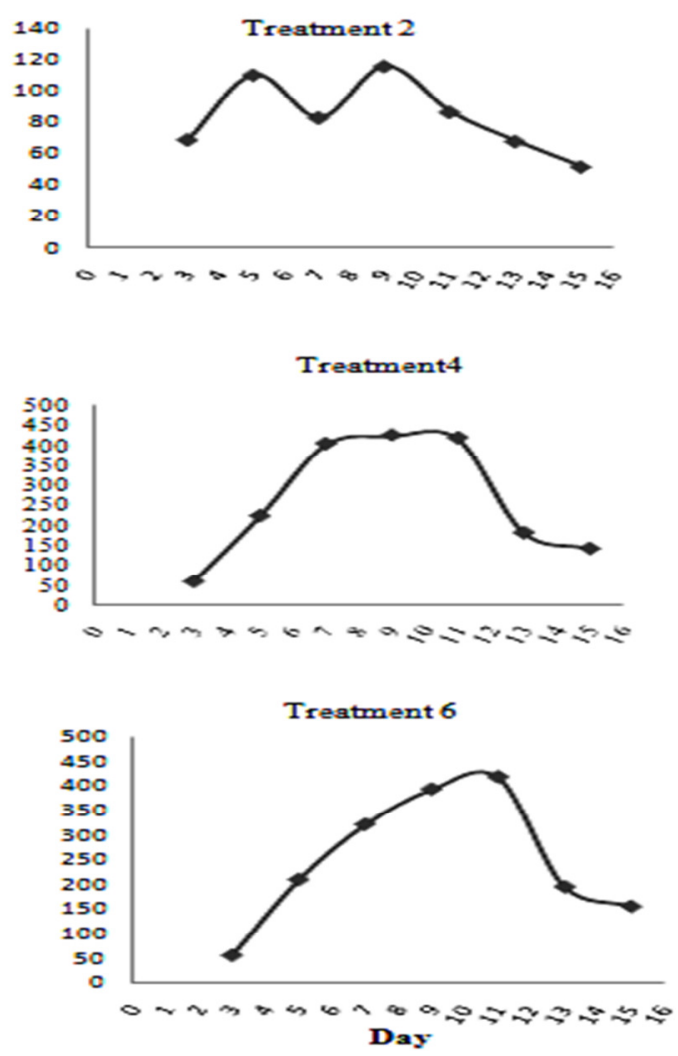


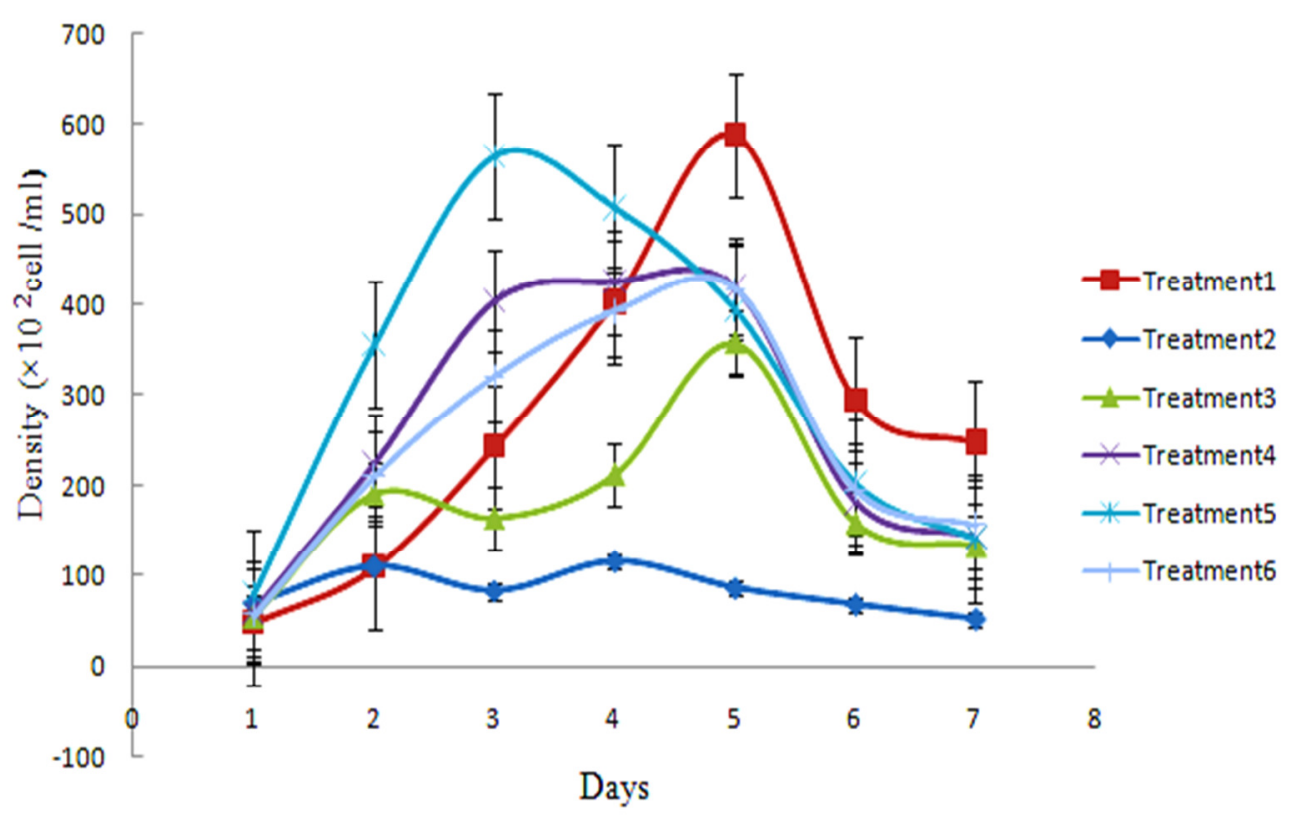

Fig.2. Spirolinaplantensis cell density in different treatments at 15 days.

Growth of Chaetoceros muelleri at different treatments: In treatment 1 (100\% f/2 Medium) cells appeared to reach their stationary phase after 9days of cultivation and started to decline thereafter. In treatment 1 maximum and minimum cell density were $\left(489 \times 10^{4} \pm 121\right)$ and $\left(179 \times 10^{4} \pm 8\right)$ for day 9 and day 5 respectively. In oneway analysis of variance (ANOVA), between days and cell density did not observed significant difference $(\mathrm{P}>0.05)$. All analyses were performed at 5\% statistical significance level. In treatment $2(80 \% \mathrm{f} / 2$ Medium $+20 \%$ urban waste) Cells appeared to reach their stationary phase after 9days of cultivation and started to decline thereafter. In treatment 2 maximum and minimum cell density were $\left(639 \times 10^{4} \pm 16\right)$ and $\left(439 \times 10^{4} \pm 8\right)$ for day 9 and day 3 respectively. In oneway analysis of variance (ANOVA), between days and cell density did not observed significant difference $(\mathrm{P}>0.05)$. All analyses were performed at 5\% statistical significance level. In treatment $3(60 \%$ f $/ 2$ Medium $+40 \%$ urban waste) cells appeared to reach their stationary phase after 13days of cultivation and started to decline thereafter. In treatment 3 maximum and minimum cell density were $\left(825 \times 10^{4} \pm 92\right)$ and $\left(63 \times 10^{4} \pm 18.5\right)$ for day13 and day 3 respectively. One-

way analysis of variance (ANOVA), showed significant difference between days and cell density $(\mathrm{P}<0.05)$. All analyses were performed at 5\% statistical significance level.In treatment $4(40 \% \mathrm{f} / 2$ Medium $+60 \%$ urban waste) cells appeared to reach their stationary phase after 9days of cultivation and started to decline thereafter. In treatment 4 maximum and minimum cell density were $\left(523 \times 10^{4} \pm 62.1\right)$ and $\left(195 \times 10^{4} \pm 6.1\right)$ for day9 and day 3 respectively. Oneway analysis of variance (ANOVA), showed significant difference between days and cell density $(\mathrm{P}<0.05)$. All analyses were performed at 5\% statistical significance level. In treatment $5(20 \% \mathrm{f} / 2$ Medium $+60 \%$ urban waste) cells appeared to reach their stationary phase after 13days of cultivation and started to decline thereafter. In treatment 5 maximum and minimum cell density were $\left(832 \times 10^{4} \pm 237.7\right)$ and $\left(71 \times 10^{4} \pm 7.1\right)$ for day13 and day 3 respectively. Oneway analysis of variance (ANOVA), showed significant difference between days and cell density $(\mathrm{P}<0.05)$. All analyses were performed at $5 \%$ statistical significance level. In treatment $6(100 \%$ urban waste) cells appeared to reach their stationary

Phase after 15days of cultivation and started to decline thereafter. In treatment 5 maximum and minimum cell density were $\left(529 \times 10^{4} \pm 190.7\right)$ and $\left(58 \times 10^{4} \pm 15.9\right)$ for day 15 and day 3 respectively. One- way analysis of 
variance (ANOVA), showed significant difference between days and cell density $(\mathrm{P}<0.05)$. All analyses were performed at 5\% statistical significance level (Fig.3) (Table.1).

Impact of different treatments and different days on the growth of Chaetoceros muelleri: Two- way analysis of variance (ANOVA) used for determination of best treatment condition and lowest time for highest Chaetoceros muelleri growth. We observed a strong positive correlation $\left(\mathrm{R}^{2}=0.70\right)$ between treatment conditions and times for Chaetoceros muelleri growth (Fig.4). The result of t-test suggested that in most of treatments (except treatment 3) at different days (except day15) did not have significant difference between both of algae ( $>0.05)$ but there was significant difference between cell density in both of algae $(\mathrm{P}<0.05)($ Fig.4) $($ Table.2).

Table.2. T-test analysis for comparison between $C$. muelleri and S. plantensis cell density in different treatments at 15 days.

\begin{tabular}{|c|c|c|c|c|c|c|}
\hline Dreatment & Day5 & Day7 & Day9 & Day11 & Day13 & Day15 \\
\hline Treatment1 s & Ns & $\mathrm{Ns}$ & Ns & Ns & Ns & $\mathrm{Ns}$ \\
\hline Treatment $2 \mathrm{~s}$ & Ns & Ns & Ns & Ns & $\mathrm{S}$ & Ns \\
\hline Treatment $3 \mathrm{~s}$ & Ns & S & S & S & $\mathrm{S}$ & $\mathrm{S}$ \\
\hline Treatment $4 \mathrm{~s}$ & Ns & Ns & Ns & Ns & $\mathrm{S}$ & Ns \\
\hline Treatment5 s & Ns & Ns & Ns & Ns & S & $\mathrm{S}$ \\
\hline Treatment6 s & Ns & Ns & Ns & Ns & S & Ns \\
\hline
\end{tabular}

S: Significant difference at confidence interval $95 \%(\mathrm{p}<0.05)$.

NS: No significant difference at confidence interval $95 \%(\mathrm{P}>0.05)$.
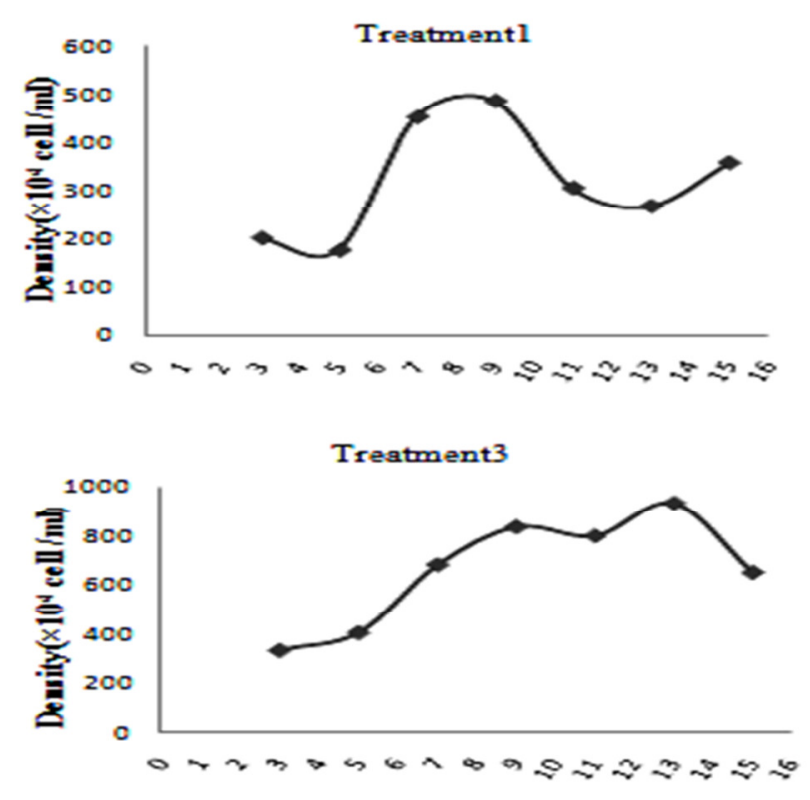

Treatment 5

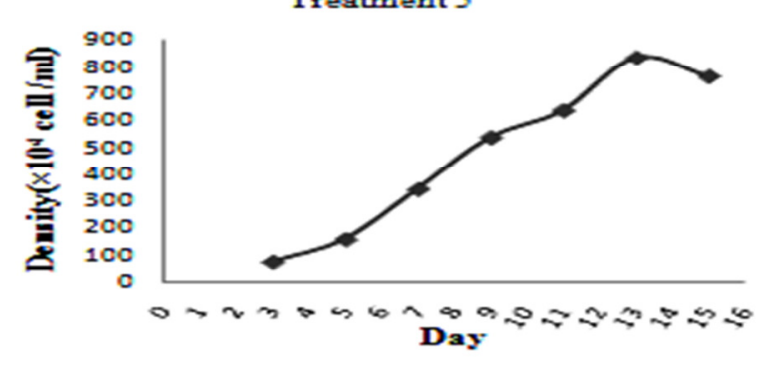

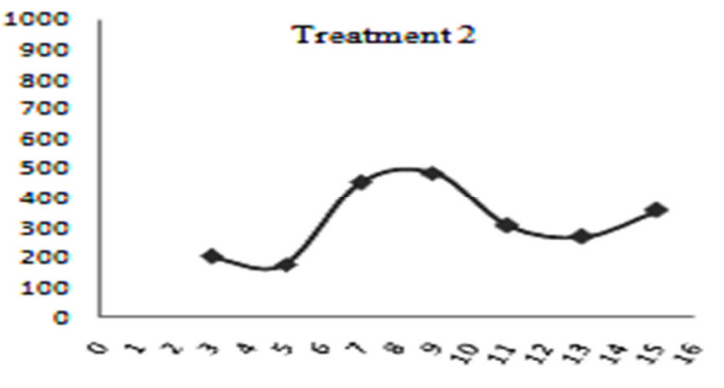
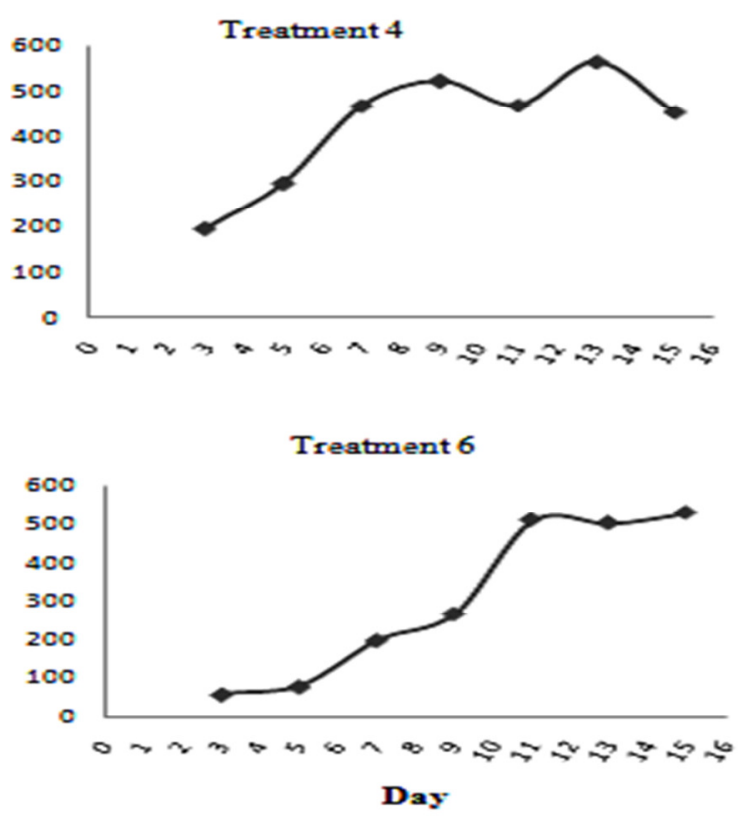


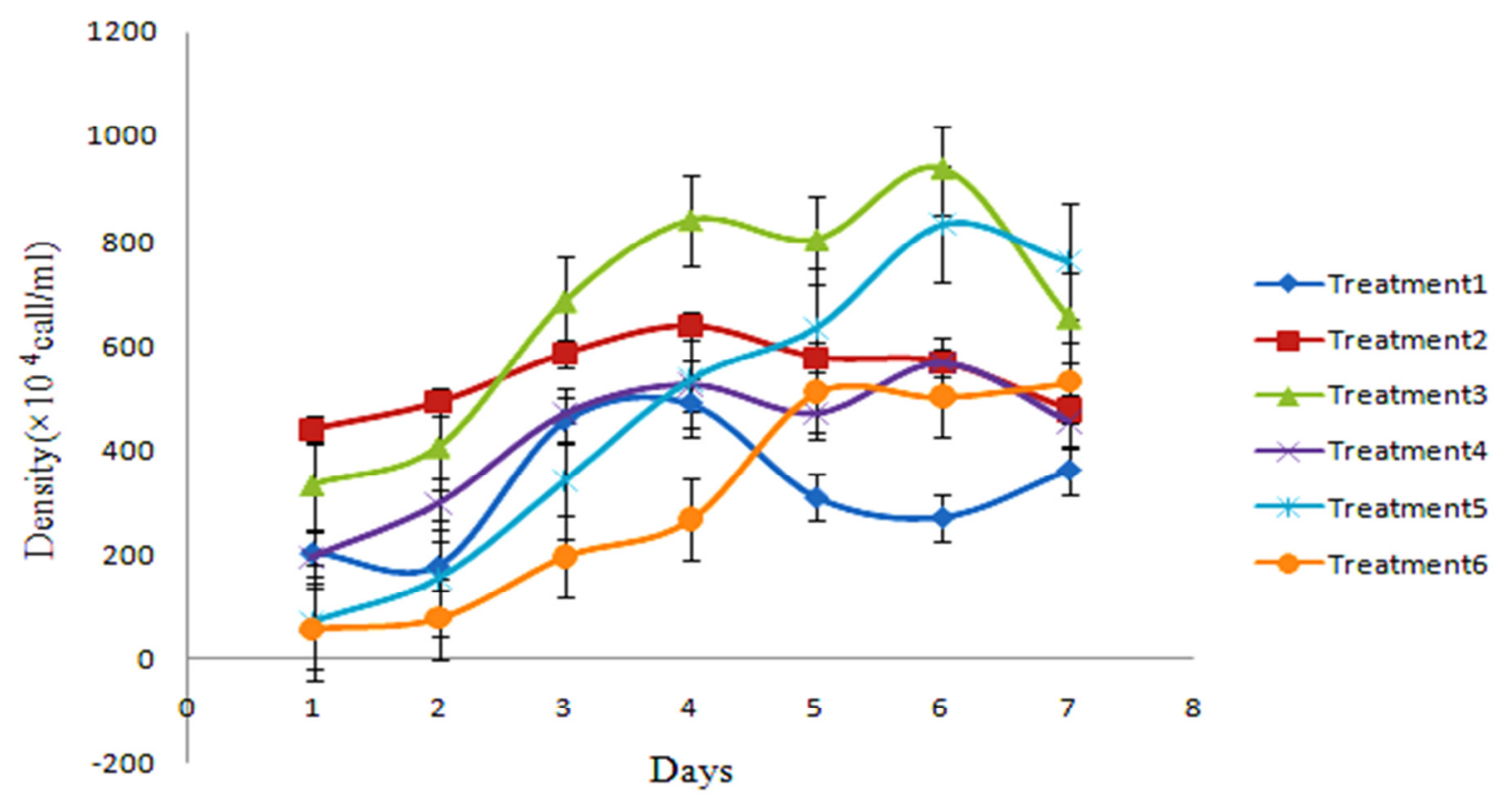

Fig.4. Chaetoceros muellericell density in different treatments at 15 days

\section{Chlorophyll a}

The mean concentration of Chlorophyll a in different treatment in Spirolinaplantensis and Chaetocerosmuelleriwere respectively $(0.169 \pm 0.06)$ $\mu \mathrm{g} / \mathrm{l}$ and $(0.173 \pm 0.06) \mu \mathrm{g} / \mathrm{l}$. The result of t-test between Chlorophyll a concentrations and two algae was showed no significant difference between
them.Total chlorophyll a contents $(\mu \mathrm{g} / 1)$ recorded inSpirolinaplantensisand Chaetocerosmuelleriwere highestat treatment $3(0.21 \pm 0.07)$ and treatment $4(0.23 \pm 0.10)$ respectively (fig.5) (Table.3).

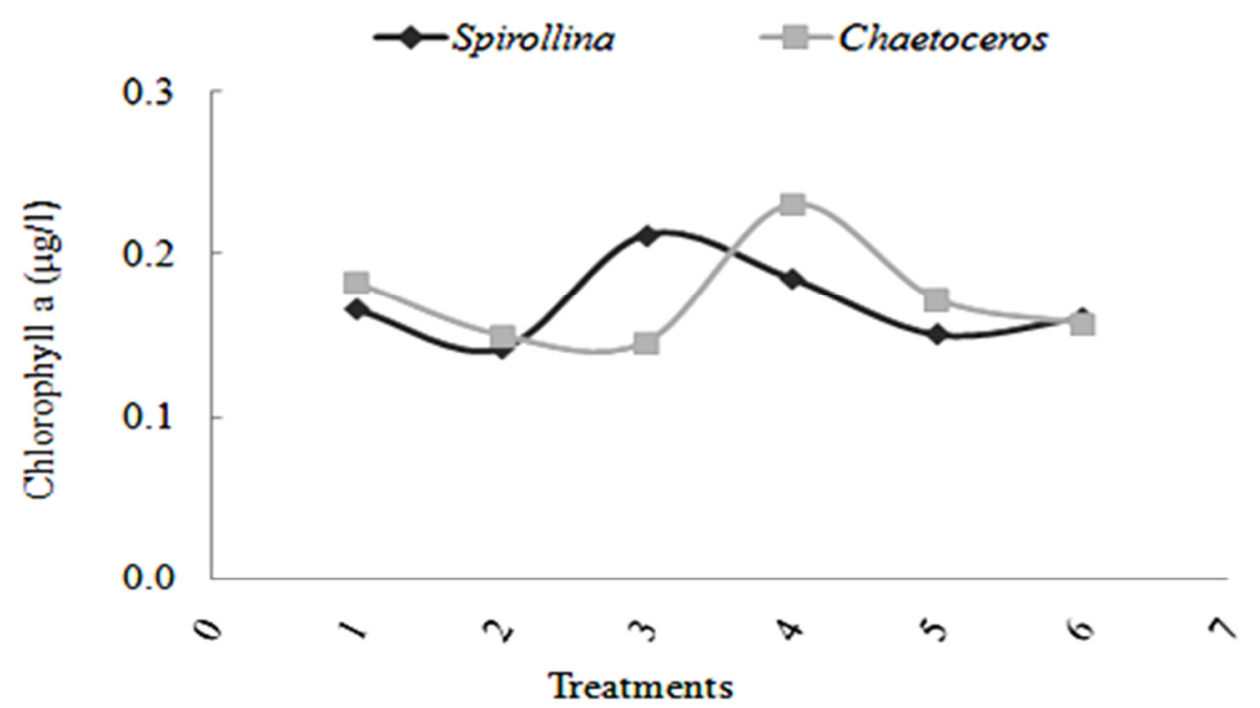

Fig.5. Concentration of chlorophyll- a, in different treatments 
Table.3. Mean and standard deviation at the end of test period (day 15)

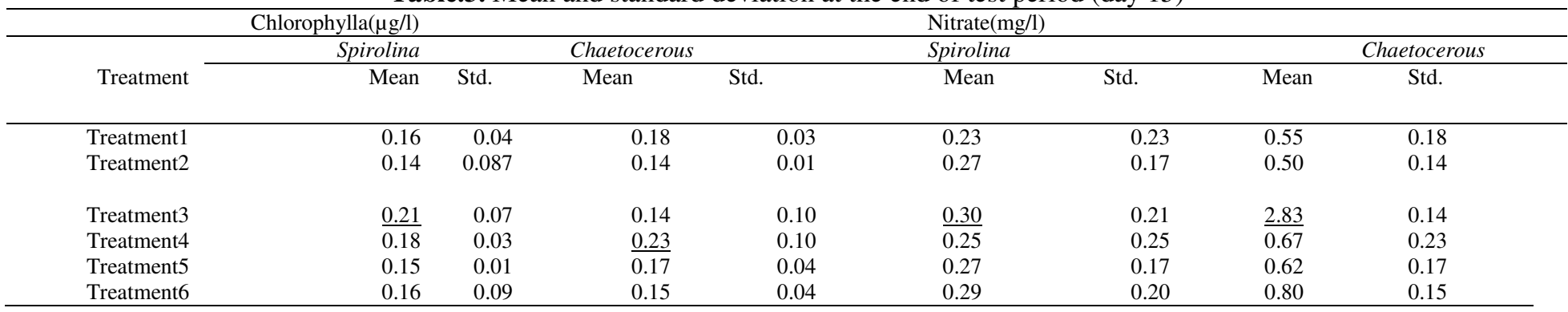

Mean and standard deviation of three replicates are shown.

Underline indicated maximum concentration.

Concentration of nitrate and phosphateinSpirolina plantensis and Chaetoceros muelleri:In this study the range of nitrate concentration inSpirolinaplantensisandChaetocerosmuelleriwere respectively between $0 \mathrm{mg} / \mathrm{l}$ to $0.56 \mathrm{mg} / \mathrm{l}$ and $0.25 \mathrm{mg} / \mathrm{l}$ to $5.0 \mathrm{mg} / \mathrm{l}$. The results of one- way analysis of variance (ANOVA) forSpirolinaplantensisandChaetoceros muelleri, suggested that there were no significant and significant difference in nitrate concentration in different treatmentrespectively.Also the range of phosphate concentration inSpirolinaplantensisand Chaetocerosmuelleriwere respectively between $2 \mathrm{mg} / \mathrm{l}$ to $31.2 \mathrm{mg} / \mathrm{l}$ and $24.5 \mathrm{mg} / \mathrm{l}$ to $61.9 \mathrm{mg} / \mathrm{l}$. The results of one- way analysis of variance (ANOVA) forSpirolina plantensisand Chaetoceros muelleri, suggested that there were significant and no significant difference in phosphate concentration in different treatments respectively (Fig.6, 7).

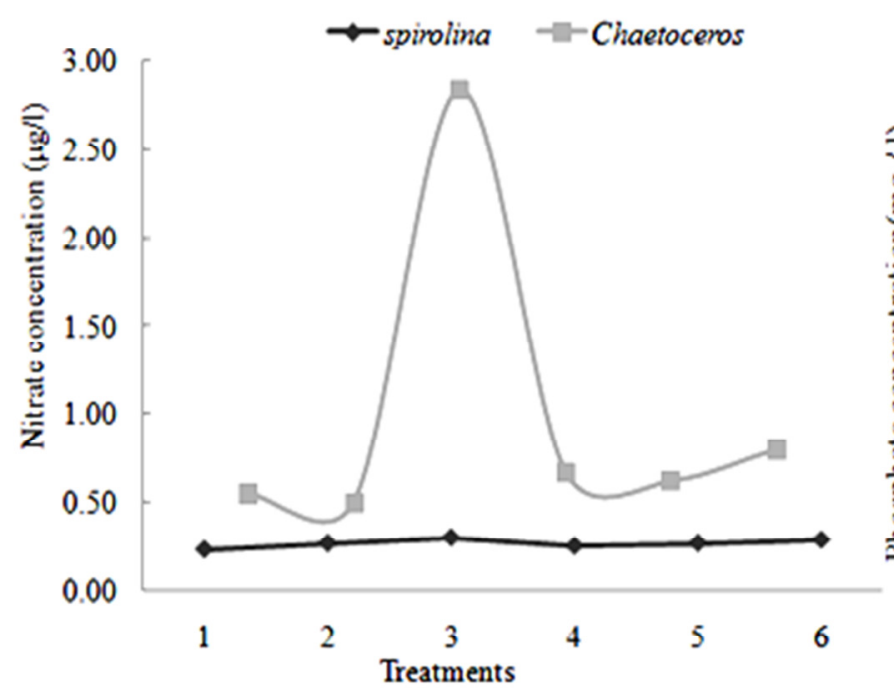

Fig.6. Concentration of nitrate in different treatments

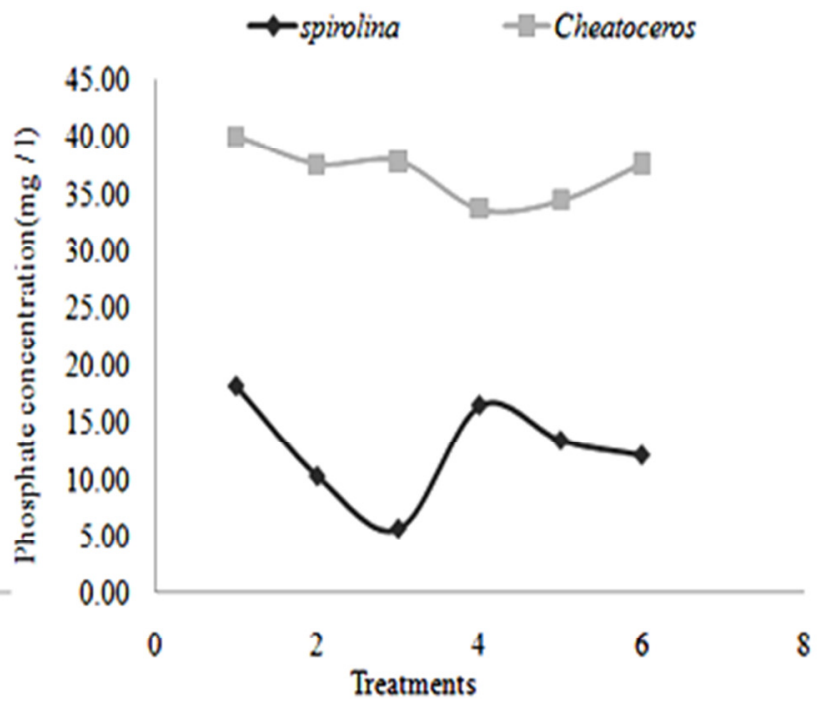

Fig.7. Concentration of phosphate in different treatments
As we know application of cyanobacterial and diatom cultures for the treatment of industrial effluents has been well recognized. Microalgae culture suggests an interesting step for wastewater treatments, because they provide a tertiary biotreatment coupled with the production of potentially valuable biomass, which can be used for several purposes. The comparisons influence two factors (treatments and days) via oneway analysis of variance (ANOVA) in Spirolinaplantensiswas more than Chaetoceros muelleri. In Spirolinaplantensismaximum cell densityat tne Iowest tımesnowea in treatment sana 0. The important note in Spirolina sp. was in all treatments, cells appeared to reach their stationary phase at day5 to day11 then started to decline thereafter. In this study existence of nitrate and phosphate in treatments was one of the main factors on Spirolinaplantensis growth at different days and the growth continued to stationary phase when enough nutrients were in media but growth decreased when the concentration of nutrients were low. Therefore we could suggest in lab conditions, the growth rate 
decreased when concentration of nutrient decreased thus not only optimum conditions affected on Spirolina plantensis but also enough nutrients are important factor to growth rate. Recent study suggested the ability of microalgae cultures in the elimination nitrogen $(50.2 \%)$ and phosphorus $(85.7 \%)$ in industrial wastewatertreatment Colak and Kaya (1988).Cyanobacteria such as Spirulinaplantensishave the great compatibility to alterations in environmental factors which could grow in wastewater and produce significant biomass. Other authors have reported the use of Spirulina plantensisgrown on Zarrouk's medium in wastewater treatment (Amala and Ramanathan 2013; Chaiklahan et al. 2013, Ismail et al. 2013). In Chaetoceros muelleri the best treatment for highest growth was treatment3 with growth pick in day 13 . The stationary phase in treatment $6(100 \%$ urban waste)occurred due to over the day because there was enough nutrients for growth Chaetoceros muelleri. Other treatments also showed an irregular growth thus the growth rate of Chaetoceros muelleri same Spirolina plantensis was depended on concentration of nutrients.Livingston et al.(2002) indicated Nitrogen was one of the chief limiting nutrients to phytoplankton through nutrient limitation experiments.

In reported papers, Lau et al. (1995)studied the higher the algal density, the better the growth and the higher the nutrient removal efficiency. The growth rate of Chaetoceros simplex was slightly enhanced with lower concentration and inhibited at higher concentrations of the effluent (Karthikeyan et al., 2010).The concentration of chlorophyll a, in Spirolinaplantensis in treatment 2 and 5 presentedexponential phase, due to increasing cell density in these treatments while Chaetoceros muelleri was not showed exponential phase in concentration of chlorophyll a. one of the main colures in microalgae is chlorophyll a, which have important role in photosynthesis and could used to indication for primary production (Strickland and Parson, 1972). The low concentration of nitrates in all treatments, suggested thatthere was no significant difference in nitrate concentration in different treatment in both of algae. Concentration of phosphate $(\mathrm{mg} / \mathrm{l})$ in both of algae in treatment $1(100 \% \mathrm{f} / 2$ Medium) was higher than other treatments thus the reductions in urban waste phosphate in all algal treatments were significantly better than those without urban waste.

Conclusion: The phytoremediation was very efficient, cost effective and eco-friendly indicating that microalgae has vital role in the removal of different pollutants from wastewater. In present investigation both the algal species had very good potential to growth in urban sewage but the urban sewage removal efficiency of Chaetoceros muelleriwas higher as compare to Spirolina plantensis which can be recommended for phytoremediation purpose.

\section{REFERENCES}

Amala, K; Ramanathan, N (2013).Comparative studies on production of Spirulina platensis on the standard and newly formulated alternative medium. Science Park. 1:1-10.

APHA(1995). Standard Methods for the Examination of Water and Wastewater, 19th Edition. American Public Health Association, American Water Works Association and Water Pollution Control Federation, Washington, DC.

Baumann, HA; Morrison, L; Stengel, DB (2009). Metal accumulation and toxicity measured by PAM-chlorophyll fluorescence in seven species of marine macroalgae. Ecotoxicol. Environ. Saf. 72: 1063-1075.

Chaiklahan, R; Chirasuwan, N; Siangdung, W; Paithoonrangsarid, K;Bunnag, B (2013). Cultivation of Spirulina platensis using pig wastewater in a semi-continuous process. Journal. Microbiology. Biotechnology. 20:609-614.

Chen, L; Zheng, QS; Liu, ZP (2009). Effects of different concentrations of copper ion on the growth and chlorophyll fluorescence characteristics of Scendesmus obliquusL. Ecol. Environ. Sic. 18: 1231- 1235.

Colak, O; Kaya, Z (1988). A study on the possibilities of biological wastewater treatment using algae. Doga. Biyolji. Serisi. 12 (1):18-29.

De la Noue, J; Proulx, D (1988). Biological tertiary treatment of urban wastewaters with chitosanimmobilized Phormidium. Applied. Microbiology. Biotechnology. 29: 292-297.

De la Noue, J;Laliberte, G; Proulx, D (1992). Algae and wastewater. Journal. Applied. Phycology. 4: 247-254.

Guillard, RRL (1975). Culture of phytoplankton for feeding marine invertebrates. In: Smith, W L; Chanley, M H (Eds.), Culture of Marine Invertebrate Animals. Plenum Press New York.

29-60.

Ismail, H; Abd El-All, AAM; Hassanein, HAM (2013). Biological influence of some 
microorganisms on olive mill wastewater. Egypt. Journal. Agriculture. Research. 91: 1-9.

Kallqvist, T; Svenson, A (2003). Assessment of ammonia toxicity in tests with the microalgae,Nephroselmis pyriformis, Chlorophyta. Water. Research. 37: 477-484.

Kapkov, VI; Belenikina, OA (2007). A Study of the resistance of mass marine algae to heavy metals. Moscow. Univ. Biol. SicBull. 62(1):30-33.

Kapkov, VI; Belenikina, OA (2003). Biomarkers of pollution of marine ecosystems with heavy metals. Water. Ecosyst. Organ (Moscow). 6: 6869.

Karthikeyan, P; Jayasudha, S; Sampathkumar, P; Manimaran, K; Santhoshkumar, C; Ashokkumar, S; Ashokprabu, V(2010). Effect of industrial effluent on the growth of marine Diatom, Chaetoceros simplex (Ostenfeld, 1901). Journal. Applied. Sciences. Environmental Management. 14.

Laliberte, C; De la Noue, J (1993). Auto- , hetero- and mixotrophic growth of Chlamydomonashumicola (Chlorophyceae) on acetate. Journal. Phycology. 29: 612-620.

Lananan, F; Abdul Hamid, SH; Din, WNS; Ali, N; Khatoon, H; Jusoh, A (2014). Symbiotic bioremediation of aquaculture wastewater in reducing ammonia and phosphorus utilizing Effective Microorganism (EM-1) and microalgae (Chlorella sp.). International. Biodeterioration. Biodegradation. 95: 127-134.

Lau, PS; Tam, NFY; Wang, YS (1995). Effect of algal density on nutrient removal from primary settled wastewater. Environmental. Pollution. 89: 56-66.

Lavajoo, F; Taherizade, M; Dehghani, M (2015).The Absorption of Nitrate and Phosphate from Urban Sewage by Blue-Green Algae (Spirolina
Platensis) (An Alternative Medium) as Application for Removing the Pollution Journal. Applied. Sciences. Environmental. Management. 19(3): 353- 356.

Livingston, R; Akshithala, J; Prasad, K;Xufeng, Niu; Sean, E; McGlyn (2002). Effects of ammonia in pulp mill effluents on estuarine phytoplankton assemblages: field descriptive and experimental results. Aquatic. Botany. 74: 343-367.

Mallick, N (2002). Biotechnological potential of immobilized algae for wastewater $\mathrm{N}, \mathrm{P}$ and metal removal: a review. BioMetals. 15: 377-390.

Mallick, N; Rai, LC (1993). Influence of culture density, $\mathrm{pH}$, organic acids and divalent cations on the removal of nutrients and metals by immobilized Anabaena doliolium and Chlorellavulgaris. World. Journal. Microbial. Biotechnology. 9: 196-201.

Nasir, NM; Bakar, NSA; Lananan, F; Abdul Hamid, SH; Lam, SS; Jusoh, A (2015). Treatment of African catfish, Clarias gariepinus wastewater utilizing phytoreediation of microalgae, Chlorella sp. With Aspergillus niger bio-harvesting. Bioresource. Technology. 190: 492-498.

Oswald, WJ (1988). Microalgae and wastewater treatment. In: Bor- owitzka, M.A., Borowitzka, L.J. (Eds.), Micro-algal Biotechnology. Cambridge University Press, Cambridge. pp. 305328.

Przytocka-Jusiak, M (1976). Growth and survival of Chlorella vulgaris in high concentrations of nitrogen. Acta. Microbiology.Pollution.25: 287289.

Rijstenbeil, JW; Derksen, JW; Gerrinda, LJ (1994). Oxidative stress induced by copper: Defense and damages in the marine planktonic diatomea grow in continuous culture with high-low zinc levels. Mar. Biol. 119: 583-590 